\title{
De gli eroici furori de Giordano Bruno: contra una lectura averroísta
}

\author{
Giordano Bruno's De Gli eroici furori: \\ Against an averroistic lecture
}

CARLOS CARRIÓN GONZÁLEZ*

\begin{abstract}
Resumen. La obra De gli eroici furori de Bruno ha sido analizada bajo muchos prismas. Ya sea bajo lecturas platónicas, cabalistas, materialistas o mágicas, la obra sigue siendo objeto de consideración por parte de los estudiosos. Este artículo examina las posturas de M. A. Granada, que muestra Los heroicos furores de Bruno bajo una interpretación nueva. Granada propone una influencia fuerte de Averroes. Finalmente, aportamos razones para sostener un averroísmo no fuerte, sino débil y colocamos la obra bajo la estela neoplatónica.

Conceptos. De gli eroici furori, platónismo, Averroes, M. A. Granada.
\end{abstract}

\begin{abstract}
De gli eroici furori Bruno's work has been analyzed from different perspectives. Either under platonic, cabalistic, materialistic or magic takes, this work is still an object of regard by scholars. The article examines M. A. Granada's stance who shows Bruno's work under a new interpretation. Granada proposes a strong influence by Averroes. In contrast, I suggest a weaker Averroes' influence that results in a neoplatonic view, which I will consider as the most accurate one.
\end{abstract}

Keywords. De gli eroici furori, hermeticism, platonism, Averroes.

\section{Introducción}

\section{a) Presentación del tema}

Conocido y afamado por las llamas que lo consumieron en 1600, el renombre de Giordano Bruno fue en aumento. El fuego que destruyó su cuerpo, lejos de provocar el olvido, le otorgó un hueco destacado en la historia del Renacimiento. Sus obras, incluidas en el índice de libros prohibidos, incautadas y quemadas todas aquellas que se encontraron, fueron recuperadas y editadas tiempo después.

Desde que toda la obra estuviera publicada y al alcance de estudiosos y profanos, la figura del Nolano se torna de difícil clasificación, secuestrado por relatos interesados. Prueba de ello es el interés por Bruno como héroe de la nación italiana con el auge del nacionalismo o el

Recibido: 05/12/2016. Aceptado: 05/10/2018.

* Graduado en Filosofía por la Universidad de Murcia (2016). Máster Interuniversitario en Investigación en Filosofía (2018). Líneas de investigación: filosofía renacentista y medieval. Contacto: carlosgonzalez1991x@ gmail.com 
relato simplista que opone ciencia y fe. Entre los estudiosos, por su parte, se lo consideraría habitualmente como un neoplatónico, habida cuenta de las referencias que a muchos de ellos hace Bruno. Una línea interpretativa dependiente de aquella sería la representada por Frances A. Yates, en una obra titulada Giordano Bruno y la tradición hermética (1964). La autora situaba a Bruno como un hábil sincretista que fundía toda una suerte de referencias cabalísticas, herméticas y neoplatónicas, unidas de manera singular en una apuesta por un pensamiento pagano que se contrapondría al cristianismo y al aristotelismo, hermanados desde siglos.

Recientemente han surgido nuevas perspectivas desde las que se explica y analiza la obra del Nolano. Se ha comenzado a ver a Bruno como un pensador fuertemente influido por Averroes en diversas tesis y aspectos. Si bien no se afirma que Bruno sea un averroísta, que siga punto a punto las argumentaciones de Averroes, sí se dice que en muchos momentos hay una relación de parentesco. Se ha señalado por ejemplo que la concepción de la materia en Bruno es deudora de la que sostuvo Averroes ${ }^{1}$. Uno de los más importantes intérpretes de Bruno a la luz del Comentador es el especialista Miguel Ángel Granada, que sostiene distintas tesis en las cuales Bruno sería deudor de Averroes². Averroizado, la interpretación de las obras de este pensador renacentista cambian sensiblemente. Bajo este prisma Los heroicos furores, junto al resto de obras, son una proclamación de la filosofía, del ámbito racional, siempre separado del discurso religioso.

En el presente trabajo mostraremos brevemente la lectura averroísta de Granada relativa a la obra Los heroicos furores de Bruno. Una vez vista dicha postura presentaremos algunas objeciones.

Tras esta parte, que podemos calificar de pars destruens, vendrá la pars construens, en la que nos proponemos tratar los elementos que creemos tienen preponderancia en la obra. Sostendremos que dichos elementos son neoplatónicos.

\section{b) Los heroicos furores}

De gli eroici furori (1585) es el texto que culmina la opera italiana. Se desmarca esta obra de las disputaciones acerca de la materia y de los aspectos cosmológicos que ocupan los cinco libros anteriores de la opera, y se da paso a un nuevo horizonte en el que se interroga por la figura del sabio. Bruno desarrolla principalmente dos géneros en el libro: el petrarquismo y la literatura de emblemas. Ambas serán aceptadas e insertadas de un modo poco conformista, pues unidas al mismo tiempo imágenes, palabras, versos, comentarios, poesía y prosa, la obra no es ni un diálogo, ni un libro de emblemas, ni un cancionero, ni un texto completamente filosófico; es una intersección de todo ello, escrito de tal modo que altera todos los géneros ${ }^{3}$.

No es casualidad que en la misma obra se hable de si hay o no que seguir reglas impuestas en poesía o en cualquier otro género. Tampoco lo es que se haga una contraposición entre las obras de invención y las de imitación, inclinándose claramente a favor de las inventivas,

1 Soto Bruna, María Jesús (1999), “Averroes en el 'De la Causa, Principio et Uno’ de Giordano Bruno. El poder de la materia”. En Averroes y los averroísmos: Actas del III congreso nacional de filosofía medieval, Zaragoza, Sociedad de Filosofía Medieval.

2 Granada, M. A. (2002), Giordano Bruno: universo infinito, unión con Dios, perfección del hombre, Barcelona, Herder.

3 Véase Ordine (2008), El umbral en la sombra, Madrid, Siruela, p. 126. 
sosteniendo entre tanto duras críticas a las normas impuestas por Aristóteles y sus seguidores a los géneros literarios ${ }^{4}$.

Tras dedicar la obra a Philip Sidney, acusa de forma reprobadora y con un lenguaje atrevido toda la tradición poética de corte petrarquista, aunque no solo, que canta la belleza de la mujer. Este no es un objeto digno de consideración para las mentes bien dotadas. Antes bien, estas deben dirigirse a la intelección de las formas y de Dios, objetos más bellos y dignos. Su intención queda expresada por las siguientes palabras:

Mi primera y principal (...) intención en la presente composición fue y es significar la contemplación divina y poner, ante la mirada y el oído ajenos, furores, no de amores vulgares, explicados en dos partes, cada una de las cuales está dividida en cinco diálogos 5 .

Los "furores", como indica el plural, son varios. Unos manifiestan ceguera e ímpetu irracional; otros, muy distintos, son frutos del esfuerzo dedicado al saber. Hay, pues, dos tipos de locuras o furores: amores salvajes y amores divinos. Nos ofrece sucintamente una clasificación de distintos furiosos:

1) En primer lugar estarían los furiosos “indignos", que identifica con el vulgo ignorante.

2) Acto seguido menciona a los "divinos", que subdivide en aquellos que son meros receptáculos de lo divino y aquellos que mediante su esfuerzo y las alas (intelecto y voluntad) se elevan a Él.

Contra los primeros ya tenemos muchas muestras de rechazo durante la obra. Siempre son mostrados como indignos, por sí y por comparación con el amor divino. No son objeto de consideración, de modo que no se les presta atención en la obra. Bruno, que se había presentado como poeta de laureles, se dedica a la función que le corresponde a tal poeta: cantar los heroicos furores instruyendo al mismo tiempo sobre ellos ${ }^{6}$.

El furioso al que canta e instruye Bruno vive un drama, pues en el afán de conseguir un conocimiento de la realidad, que se presenta como infinita, no puede sino malograr su objetivo. La realidad es un objeto tan inabarcable que no puede ser comprendido de modo completo por la mente humana, porque aquella excede a esta por entero. Lo finito no puede adquirir lo infinito. Mas esto no excluye que lo infinito pueda ser infinitamente buscado y anhelado. La figura del filósofo en Bruno ejemplificará el ansia y la derrota de la mente humana.

La miseria de la filosofía y del filósofo es perseguir lo que no puede aprehender de modo completo. En la búsqueda del infinito, el filósofo o heroico furioso se sirve de dos instrumentos: el intelecto y la voluntad. Mediante la unión de ambos, el furioso se lanza a la búsqueda de conocimiento, que en términos visuales se presentará mediante el mito de Acteón y Diana. Acteón será el furioso que se dirige a la caza de Diana (la naturaleza). En tal caza Acteón se diviniza al obtener conocimiento.

4 Sobre todo esto véase Bruno, G. (1987), Los heroicos furores, Barcelona, Tecnos, pp. 29-44.

5 Furores, p. 12.

6 El pasaje al que aludimos se hace una contraposición entre el poeta de laureles y el de mirtos. El primero tiene como objeto el heroico furioso; el otro se identificaría con los poetas de corte petrarquista que cantan amores y furores indignos. Furores, p. 31. 


\section{La propuesta de Miguel Ángel Granada}

\section{a) Bruno averroísta}

Miguel Ángel Granada propone que el Comentador tiene una gran importancia en la génesis y el desarrollo del pensamiento bruniano. Detectada su influencia en la opera italiana, se puede decir que hay unas orientaciones marcadas y que son propias del averroísmo. Las orientaciones presentes que detecta Granada son tres:

1) La religión queda como un discurso mitológico con funcionalidad práctica (social principalmente).

2) La filosofía es el camino por el cual se perfecciona el hombre.

3) El discurso filosófico es independiente y suficiente para hallar la verdad.

No es extraño que Miguel A. Granada diga entonces que "Averroes está presente allí donde se afirma la independencia de la filosofía y por tanto el carácter profesional del filósofo"?.

En lo que respecta a Los heroicos furores, esto se puede detectar, según Granada, en más de una ocasión en la obra. Destaca la comparación entre tres tipos de mentalidad que Averroes señalara (la del vulgo, la de los teólogos y la de los filósofos) ${ }^{8}$ y que parece que Bruno acoge en varios momentos de la obra italiana y en De gli eroici furori. El filósofo estaría en la cúspide de estos tres tipos de mentalidad. Sería aquel que se ha elevado por encima de las verdades a medias del vulgo, pero también de las del clero. Con su razón llega a un estatuto gnoseológico que le está vedado a los dos anteriores.

Miguel Ángel Granada subraya que lo que se hace es una suplantación por parte del discurso filosófico respecto del teológico, una proclama en pos de la independencia del filósofo. Además, el enaltecimiento del hombre no se procura mediante la fe, sino a través del empleo de la razón y su desenvolvimiento en el discurso filosófico. Granada en un momento afirma que el "furioso" de Bruno no es sino el sabio averroísta y sostiene que esta es la clave bajo la cual hay que interpretar Los heroicos furores. Visto así, este libro es una obra averroísta:

De momento, no obstante, constataremos que Bruno ha fundido con la figura del filósofo averroísta la otra del furioso enamorado de la divinidad, presente en la tradición del amor platónico y propuesta a la cultura del Renacimiento por Ficino en su De amore $^{9}$.

\section{b) ¿Averroísmo en el Renacimiento?}

M. A. Granada cuando nos habla de la pervivencia del averroísmo en el Renacimiento recurre a grandes valedores que se suelen colocar bajo esa estela en la historiografía: Pomponazzi, Zabarella y Cremonini. También recuerda las voces contrarias a Averroes:

7 Granada, M. A. (2002), Giordano Bruno: universo infinito, unión con Dios, perfección del hombre, Barcelona, Herder, p. 21.

8 Ibíd., p. 35-42, 275-280.

9 Ibíd., p. 45. 
los ataques de Petrarca, acusándole no solo de ser contrario a muchas enseñanzas de la fe (eternidad del mundo, intelecto separado, etc), sino también por pervertir a Aristóteles al no tener los conocimientos necesarios de griego para leerlo en el original. El hecho que más resalta Granada para atestiguar la presencia de averroísmo es que, a finales del siglo XV, se publica en Venecia la obra completa de Aristóteles junto a los comentarios de Averroes.

A pesar de aquellos datos, queremos recordar las objeciones que Kristeller empleara contra el uso generalista de averroísmo en el período que comprende el Renacimiento ${ }^{10}$ :

Si llamamos averroístas solamente a los aristotélicos que concuerdan con Averroes en la interpretación de cada uno de los pasajes de Aristóteles, difícilmente podremos encontrar un solo averroísta. Si llamamos, empero, averroístas al pensador que toma algunas opiniones de los comentarios de Averroes, apenas encontraremos un solo aristotélico que no pueda llamarse averroísta ${ }^{11}$.

Si esquivamos estas posturas incómodas, nos queda atarnos a llamar averroísta a quienes confesaran adhesión en las doctrinas estrictamente averroístas. Normalmente se esgrimen dos: la tesis de la unidad del intelecto y la de la doble verdad. Ambas son desmontadas por Kristeller, pero lo que a nosotros nos interesa es ceñirnos a la correcta idea de que no por compartir algunas opiniones con el Comentador se es averroísta. En ese sentido difícilmente se puede decir que haya averroísmo o averroístas en el Renacimiento.

Que Bruno pudiera compartir algunos puntos de vista con Averroes es natural dada su familiaridad con Aristóteles. Hemos de notar que Nápoles fue uno de los primeros centros de Italia donde arraigó el aristotelismo y es allí, en un convento dominico, donde Bruno recibió gran parte de su formación hasta que decidió marcharse de Italia, camino de la corte francesa de Enrique III. No olvidemos que Bruno tenía un conocimiento amplio de Aristóteles ya que su propuesta cosmológica se construye contra la del Estagirita. Un hecho viene a añadirse sobre el resto: durante su vida ejerció como profesor impartiendo cursos sobre temáticas aristotélicas. Dos fueron los momentos en que impartió clases sobre el Estagirita: antes de ir por primera vez a París estuvo dos años en Tolosa dando clases sobre aquel; la segunda, mucho después, sería en Wittenberg, donde estuvo otros dos años ${ }^{12}$.

Concedemos, pues, que el Nolano leyó a Averroes y muestra alguna influencia del mismo, pero en modo alguno se puede acercar su pensar al del pensador musulmán. Más que una presencia fuerte del Comentador, debemos señalar una débil, punto compartido por todos los lectores de Aristóteles, ya que todos leían en algún punto sus comentarios, ora a favor, ora en contra. En este sentido no tiene ninguna relevancia remarcar las similitudes que indica Granada: todo lector de Aristóteles, ya fuere en un punto o en otro, se avendrá en conformidad con Averroes en algunas cuestiones. Nos preocuparemos más detenidamente de desatar el nudo que crea Granada entre el furioso y el sabio de Averroes.

10 Kristeller, P. O. (1986), El pensamiento renacentista y las artes, Madrid, Tecnos, pp. 130-133.

11 Ibíd., p. 132.

12 Kristeller, P. O. (1970), Ocho filósofos del renacimiento, México, Fondo de cultura económica. 
c) Observaciones críticas a la propuesta del furioso heroico como sabio averroísta

1) Primero de todo tenemos que para Bruno Dios es infinito y, en virtud de ser un "ápeiron”, de no tener límites, no puede ser aprehendido por la mente humana ni por ninguno de sus discursos o conceptos. Hacer un discurso filosófico sobre lo real es ya poner limitaciones y alienar lo que no puede expresarse de forma finita ${ }^{13}$. El modo en que el filósofo furioso lo conoce es distinto al averroísta: mientras que este lo conoce mediante argumentación filosófica y da una serie de proposiciones sobre Él, aquel, el furioso, solo es consciente de que Él está más allá de lo que pueda concebir. Lo poco que sabe es mediante su reflejo en las cosas. Tenemos, por tanto, un discurso que da contornos precisos a lo que Dios sea, mientras que el otro apenas puede decir algo.

2) Después, y en relación con el anterior punto, tenemos que el furioso bruniano es un ser siempre insatisfecho, que en el intento de la caza, nunca halla lo que pretende. Por eso, en multitud de ocasiones el furioso es caracterizado no como un ser feliz y autosuficiente... más bien lo contrario. El furioso es un ser atormentado, insatisfecho e infeliz ${ }^{14}$. En cambio, el sabio de Averroes es caracterizado, al igual que el sabio en Platón y Aristóteles, como un ser mucho más feliz que el resto de humanos. Si se presenta al sabio como un ser que es miserable y que lejos de ser autosuficiente está encadenado, difícilmente podremos decir que este sabio sea el sabio de Averroes, de Platón o de Aristóteles.

3) Tenemos, además, que el furioso bruniano es de muchos tipos y, como Bruno mismo señala en el principio del tercer diálogo de la primera parte, los hay que lo son sin esfuerzo ni conocimiento alguno ${ }^{15}$ (si bien la obra no se dedica al estudio de ellos). Como resultado de esto, hemos de concluir que el furioso puede serlo siendo un ignorante. ¿Puede ser el sabio averroísta un ignorante? Ciertamente no. Si lo fuera no sería un sabio, porque no es posible un sabio inculto, sin discurso filosófico, en Averroes.

4) Hablando sobre cómo podía detectarse la presencia de pensamiento averroísta, Granada afirma que Averroes se halla presente, siempre, en todo aquel discurso que haga distinción entre el discurso filosófico y el teológico. En ese caso debemos ser precavidos. Kristeller ya se percató de que tal distinción era muy común y no siempre se puede atribuir a averroístas. Como dice al tratar sobre las ambigüedades del término averroísta:

Si limitamos el término a aquellos pensadores que trazaban una distinción entre la filosofía aristotélica y la teología cristiana, prácticamente todos los profesores de filosofía - a diferencia de los teólogos- adoptaron esa posición, desde finales del siglo XIII hasta el XIV e incluso posteriormente ${ }^{16}$.

5) Creemos que, tal y como es presentada la equiparación que hace Granada, esta pierde especifidad y se convierte en algo no suficientemente vinculante. Veamos un ejemplo:

13 Furores, p. 66.

14 Furores., pp. 47, 101, 118-121, 172.

15 “(...) ciertos individuos, al haberse convertido en habitáculos de dioses o espíritus divinos dicen y obran cosas admirables de las que ni ellos mismos ni otros entienden la razón; son estos generalmente elevados a tal situación desde un primer estado de incultura e ignorancia". Furores, p. 56-57.

16 Kristeller, El pensamiento renacentista y sus fuentes, p. 59-60. 
(...) y Bruno sabe con la tradición filosófica (con Platón y Plotino; con Aristóteles y la tradición peripatética; con Averroes y el llamado "averroísmo latino" o "aristotelismo radical") que la perfección del intelecto por el conocimiento de los objetos inteligibles máximos constituye la máxima expresión de la humanidad, el estado supremo accesible al hombre y, por tanto, la "la perfección humana". En ese estado y en esa forma de vida se da también, lógicamente, la suprema felicidad o beatitudo accesible al hombre ${ }^{17}$.

Creemos firmemente que esto no puede decirse o formularse de este modo. En primer lugar por la segunda de las razones que hemos dado en este apartado pero, concediendo que eso no fuera cierto, ¿qué nos quedaría? Si decimos que Platón, junto a todos sus seguidores, que Aristóteles, junto a los suyos y que Averroes y sus discípulos están de acuerdo en lo mismo, ¿por qué decir entonces que la clave interpretativa de Los heroicos furores es el sabio averroísta? Si todos tienen un ideal de sabio que concuerda a grandes rasgos habrá que decir que el furioso bruniano es tan averroísta como aristotélico o platónico y, en consecuencia, no se puede decir que el filósofo averroísta nos dé la clave interpretativa de esta obra.

\section{Elementos neoplatónicos}

\section{a) Lo incognoscible Uno}

El rasgo de lo incognoscible para el principio de la realidad queda recogido tempranamente en la República. Allí, el ser o las formas resultan no ser el fundamento último de lo real, sino que el fundamento se sitúa más allá de las formas. Tal principio es el Bien. Platón siempre mantuvo la ecuación parmenídea en la que ser y conocer iban de la mano, pues creía que no hay nada que sea y no pueda ser entendido y, al mismo tiempo, no hay nada que pueda ser entendido y no sea. Sin embargo, al postular un principio que está por encima del ser (y que no es ser) esa ecuación se rompió en Platón ${ }^{18}$. Esto sienta precedente, y en el resto de la literatura neoplatónica se afirmará que el ser se halla sujeto a un principio que no es ser y que, por tanto, ni puede conocerse ni expresarse. La ousía pasaba así a un segundo lugar y depende de algo que la trasciende por completo. La asunción explícita de esto llega con Plotino y su Uno, pero también con Proclo, quien en la Institutio theologica expresa con claridad que el ser es una de las primeras cosas creadas.

Con la llegada del cristianismo es asumible pensar que alguna modificación debiera ser hecha a lo que se ha comentado. Esto, sobre todo, porque en Éxodo III, 14 Dios se autodenomina diciendo: "Yo soy el que es". Partiendo de aquí es difícil creer que el cristianismo pudiera conciliarse con el platonismo tal y como quedó expresado en la Antigüedad, con su principio incognoscible y que antecedía al ser. Qué paradoja resultaría al verse que lejos de ocurrir una separación se incorporarían perfectamente estos dos elementos que aparentemente no podían darse unidos.

17 Granada, Giordano Bruno, p. 318.

18 “-Y así dirás que a las cosas cognoscibles les viene del Bien no sólo el ser conocidas, sino también de él les llega el existir y la esencia, aunque el Bien no sea esencia, sino algo que se eleva más allá de la esencia en cuanto a dignidad y poder". Platón (1982), Diálogos IV, República, VI 509b, Madrid, Gredos. 
En el Pseudo-Dionisio Areopagita sería el máximo exponente al proponer que Dios no puede conocerse de ningún modo. No podemos saber qué es Dios. Debemos conformarnos, humildemente, con saber que Él no es nada de cuanto conocemos, ninguna de las cosas que es dada a nuestros sentidos o nuestro intelecto. Fuera de lo que puede concebirse, el Dios del Areopagita se honra más con el silencio, como dice Bruno, que con discursos que lo tomen como tema sobre el que investigar. El Pseudo-Dionisio se une el concepto neoplatónico de Uno con Dios, dando como resultado algo incognoscible, innombrable, algo ante lo que solo queda el silencio:

(...) cuando intenta subir desde las cosas de abajo hasta lo Sumo, a medida que sube comienzan a faltarle palabras y cuando ha terminado ya la subida se quedará totalmente sin palabras $(\ldots)^{19}$.

Y esta línea todavía daría frutos siglos después. Meister Eckhart fue ejemplo ya que su postura fue clara: "El ser no le pertenece a Dios, ni el ente, y Él es algo más alto que el ente" 20 . Vemos, pues, que contando con las vicisitudes e inflexiones que la tradición platónica iría adquiriendo con los distintos epígonos que lo avalaron se mantiene unido en este punto, razón por la cual se ha dicho que el misticismo es el lugar común al que todo platónico llega ${ }^{21}$.

Bruno es heredero de estos planteamientos y no por mero azar menciona a Dionisio Areopagita, mostrándose afín a la opinión de que tratar sobre cosas divinas no es sino humillar esas cosas ${ }^{22}$. También en Bruno lo divino escapa al intelecto.

Cuando se establece que la meta del furioso es la búsqueda de la divinidad mediante el conocimiento, se tiene que pronunciar sobre una problemática: ¿puede Dios conocerse a través del intelecto o puede solamente amarse? La respuesta es complicada y debe conjugarse con la temática del principio incognoscible. Acaba declarando que ambas alas son necesarias para ascender hasta donde se pueda, no hasta la cima, pero sí hasta donde pueda el hombre. Por esto, dice que amamos en cierto sentido lo que entendemos y viceversa, que aquello que entendemos lo amamos ${ }^{23}$. Así lo expresa al principio de su obra. Por lo tanto, las dos alas platónicas (razón y voluntad) no pueden alcanzar una comprensión completa de lo infinito, pero ello no nos hurta la posibilidad de buscar comprenderlo infinitamente, hasta el último hálito vital que el furioso posea ${ }^{24}$. Mas surge otra dificultad: ¿cómo algo que es infinito puede ser expresado por nuestras explicaciones? La naturaleza de todo discurso es limitante: la madeja de conceptos dan cuenta de algo limitado y, en cuanto limitado, no es algo infinito lo que se explica. En otras palabras, no se puede mediante nuestras teorías captar la realidad infinita de Dios:

19 Dionisio, Pseudo (2007), Obras completas., Madrid, Biblioteca de autores cristianos, p. 252.

20 Citado en Gilson, E. (2009), El ser y los filósofos, Pamplona, Eunsa, p. 64.

21 Ibíd., p. 65.

22 "De ahí que dijera con acierto un teólogo que, siendo la fuente de la luz con mucho superior, no solamente a nuestras inteligencias, sino incluso a las inteligencias divinas, es cosa conveniente que sea celebrada, no con discursos y palabras, sino por el silencio". Cfr. Furores, p. 146.

23 Furores, p. 17.

24 Furores, pp. 100-101. 
(...) nuestra potencia intelectiva no puede aprehender el infinito sino en discurso o en cierta forma de discurso (...) el héroe es como aquel que pretende la consecución de lo inmenso, viniendo a establecer un fin allí donde no existe fin ${ }^{25}$.

A pesar de observar estas continuidades que van desde la Antigüedad hasta el Nolano, hemos de purgar posibles malentendidos: De gli eroici furori no se mueve dentro del ámbito de la mística. Pese estar a las puertas de la misma no llega a ingresar. Acudimos a la propia palabra de Bruno en apoyo de este esclarecimiento. Son varias las ocasiones en las que se dice que su discurso está regido por un marco racional que nada tiene que ver con misterios. La primera vez que trata el tema es al principio de la obra ${ }^{26}$. Es claro entonces que esta no es una obra mística, pero claro es también que en Bruno el principio de todo presenta los rasgos que presentara en Platón, en Plotino o en Dionisio Areopagita: el Uno o Dios nos trasciende de tal modo que no hay manera de acercarnos a él.

\section{b) La importancia de lo visual en Los heroicos furores}

Eugenio Garín decía de Ficino que tenía predilección en su modo de expresarse por dos recursos: mitos e imágenes. En su búsqueda de Dios en las cosas, de lo que quedaba de vestigio de las formas en los apareceres de este mundo, hallaba un aliado en la imagen. Garín decía que este gusto por la imagen y la alegoría no era solo un gusto particular del pensador florentino. Antes que eso era la expresión de cierto lugar común del platonismo: la imagen es un medio más adecuado que la palabra o el concepto a la hora de alcanzar las formas ${ }^{27}$. Creemos que no es casualidad la importancia de lo visivo en la obra de Bruno y que se puede ligar a esta corriente subterránea que da forma a varias fuentes del neoplatonismo. Detengámonos brevemente en la obra titulada Candelero, el libro que inaugura el ciclo de obras italianas.

Nuccio Ordine, en su análisis del Candelero, señala el choque entre realidad y apariencia como el principal tema de la obra, encubierta bajo la humilde forma de comedia. En este libro se expresa el juego entre lo real y lo aparente. Captar el sentido de la comedia tiene como condición previa el "desvelamiento" de lo real respecto a lo aparente. De ahí que haya una continua incitación a "ver".

Para «ver» no solo sirven los ojos. Se «ve» también con los «ojos de la mente». La luz del Candelero (...) promete aclarar un poco ciertas «sombras de las ideas». En el mismo año, 1582, Bruno publica en París el De umbris idearum y el Cantus circaeus. Dos textos sobre mnemotecnia, donde, en diversos planos y con lenguajes diferentes, el Nolano propone su itinerario «visivo». Si en el De umbris se ve a través de imágenes que se combinan con el giro de cinco ruedas, en el Cantus se ve a partir de la diferencia entre forma externa y sustancia interna, entre extra e intus. En ambos

25 Furores, p. 66.

26 Furores, p. 7. Allí dice de su proceder: "mi natural y físico discurso".

27 Garin, E. (1984), La revolución cultural del renacimiento, Madrid, Crítica, p. 153. 
casos se trata de unificar lo diferente, tratando de distinguir en la multiplicidad de apariencias la verdadera esencia de las $\operatorname{cosas}^{28}$.

Ordine afirma que Bruno se ve a sí mismo de forma polifacética: como filósofo, sí, pero también como pintor y poeta. Pintura, poesía y filosofía emplean imágenes.

Y solo a través de las imágenes se dice lo indecible, se ve lo invisible. Inmerso en el fluir de las sombras, el conocimiento del hombre difícilmente puede valerse de otro medio. El Nolano «pinta» en el Candelero, pero también en el resto de la obra londinense parece concretarse bajo el signo de una especie de «filosofía-poesía-pintura» ${ }^{29}$.

Aunque Ordine no enlaza esta raíz polifacética de Bruno con el platonismo, nos parece que la suposición de que haya un nexo de unión entre el uso de imágenes en el mismo sentido en el que los neoplatónicos lo emplean no es descabellada. Plotino vino aquí a asistir a los vástagos del neoplatonismo. Gombrich ya señaló estas influencias respecto a este tema al indicar un pasaje de Enéadas V, 8 que haría fortuna en el Renacimiento:

No hay que pensar que en el Mundo Inteligible de los dioses y los bienaventurados vean proposiciones; todo lo allí expresado es una hermosa imagen ${ }^{30}$.

Esta intuición del neoplatonismo tuvo una puesta en escena con mayor fuerza en el Renacimiento que en otras épocas por dos motivos:

1) El platonismo se desarrolla con mayor vigor en el Renacimiento que en el Bajomedievo, en el que apenas si se tenían en el Occidente latino los comentarios de Calcidio al Timeo junto a un buen número de fuentes indirectas como la Consolatio de Boecio, el Pseudo-Dioniosio Areopagita o Agustín de Hipona ${ }^{31}$. Plotino no fue traducido por completo hasta que se encargó de ello Ficino, que también lo glosó con comentarios. En las Enéadas, Plotino se mostraba favorable a creer que la lengua ideográfica egipcia formaba parte de un tipo de conocimiento superior que se valía de imágenes como vehículo de transmisión, descartando el pensamiento discursivo y las posibles malinterpretaciones que de este se pudieran derivar ${ }^{32}$. Avivó este fuego el descubrimiento de un manuscrito griego llamado Hieroglyphica de Horapolo, que fue encontrado y adquirido en 1519 en Andros por el sacerdote florentino Cristoforo Buondelmonti y llevado a Florencia poco después, despertando interés en los círculos neoplatónicos ${ }^{33}$.

2) Pero no podemos reducir el uso de imágenes en esta época a las intuiciones neoplatónicas. El Renacimiento estaba cultivando por sí mismo un gusto por la imagen. Los Emblemas de Alciato, por ejemplo, no tiene ninguna pretensión, más allá de la educativa

28 Ordine, N. (2008), El umbral de la sombra, Madrid, Siruela, p. 74.

29 Ibíd., p. 75.

30 Cfr., Gombrich, E. H. (1986), Imágenes simbólicas, Madrid, Alianza, p. 246.

31 Cfr. Klibansky, R. (1981), The continuity of the platonic tradition during the middle ages, Kraus International publications. También Kristeller (1982), El pensamiento renacentista y sus fuentes, México, FCE.

32 Cfr., Gombrich, Imágenes simbólicas, pp. 244-270.

33 Véase Praz, Mario (2005), Imágenes del Barroco, Madrid, Siruela, pp. 24-26. 
o moral, en el empleo de imágenes pero consiguió una difusión inusitada con más de cincuenta ediciones.

Resumiendo, el empleo de imágenes formaba parte de una tendencia propia del neoplatonismo, que explota el carácter alusivo para señalar aquello que no puede señalarse, pero también se empleaba porque se había generado durante el Renacimiento un gusto por lo icónico, que había encontrado en la imprenta un gran aliado a la hora de abaratar costes y extender la cultura de la imagen. Podemos, pues, distinguir dos tipos de literatura que emplean las imágenes: una que se desarrolla, a modo de sustituto de los antiguos jeroglíficos, una especie de lenguaje ideal que pretendía contener conocimientos sobre las verdades supremas; el otro, con menos pretensiones, utiliza el emblema con la única intención de inculcar verdades de tipo ético-religiosas ${ }^{34}$.

Nos parece que Bruno emplea los emblemas no de forma desinteresada: por un lado, puede ser una manera de atraer un mayor público que, familiarizado con la extensa literatura emblemática de la época, pudiera sentirse atraído por este libro heterodoxo, que emplea emblemas, poemas y prosa de modo peculiar y discordante con los géneros tradicionales; por otro, da cabida al tópico, al que alude Garín que es propio del platonismo, aunque no estemos de acuerdo con aquellos que entienden que este uso signifique un retorno al uso de símbolos egipcios ${ }^{35}$.

Esta interpretación, si bien es de un gran interés, creo que podemos descartarla, porque la imagen, según estos intérpretes, está al servicio de la búsqueda de una lengua originaria mientras que, tal y como vemos que es empleada en Los heroicos furores, Bruno pretende más bien ilustrar o facilitar al lector la comprensión del texto. Busca mediante la imagen y la palabra aquello que es infinito e inexpresable. Pretende hacerlo visible, aunque sea de forma marginal, a los ojos de la razón.

Nótese que la importancia de lo visual en la obra de Bruno no queda restringido al empleo de imágenes en forma de emblemas. El mismo mito de Acteón tiene familiaridad con el problema de lo visivo. Se escoge con toda intencionalidad, pues en él la mirada es el elemento desencadenante de la metamorfosis del furioso. A causa de la observación de lo divino bello se ocasiona la transformación, el acrecentamiento del hombre que se diviniza. Ver, pues, es el centro de gravedad del mito. Si Acteón no penetrara con su mirada la íntima naturaleza de lo inteligible (personificada en Diana) nada pasaría.

Hay que señalar, como colofón a este apartado, que no es la primera vez que se une el acto visivo, un mito y la comprensión que es resultado de la indagación filosófica. Ya Plotino en las Enéadas ligaba la comprensión y el ver con los ojos de la mente, si bien de forma pasajera, con un personaje mítico: con Linceo, del que "se decía que veía aun las entrañas de la tierra" 36 .

\footnotetext{
34 Ibíd., p. 195.

35 Yates, Frances (1983), Giordano Bruno y la tradición hermética, Barcelona, Ariel, p. 326.

36 Plotino (1998), Enéadas, V 84 25-30, Gredos, Madrid.
} 


\section{c) La caza de lo divino}

La temática escogida por Giordano Bruno recoge, en nuestra opinión, un tercer elemento que es explotado por el neoplatonismo. Tal es el elemento de la caza. Usualmente se ha señalado la metáfora de la caza atendiendo a los registros pictóricos y poéticos donde la figura de Acteón hizo fortuna ${ }^{37}$, pero se ha ignorado el potencial juego que ha desatado la metáfora de la caza en ciertos filósofos neoplatónicos. Bajo su lectura segura, afirmamos que Bruno se guía.

El inicio de ese recorrido acudiríamos a Raimundo Lulio, que ya en el s. XIII, emplea con cierta asiduidad el término "venatio" para la captación de conceptos ${ }^{38}$.

La senda abierta por Lulio fue seguida por un epígono de relevancia como fue Nicolás de Cusa. Sabemos que su primer contacto con Lulio se hizo a través de un libro regalado que le obsequió el obispo Dandolo de Padua. Gracias a él descubrió el texto Lectura super artem inventivam et tabulam generalem. Fue el inicio de una pasión que le llevó a tener en su propia biblioteca 77 obras lulianas ${ }^{39}$. En 1463 publicó La caza de la sabiduría (De venatione sapientiae), donde hace honor a la metáfora de la caza del conocimiento. Sin embargo, Bruno recoge del Cusano más la figura del docto ignorante, del que el furioso resulta trasunto a medias.

Marsilio Ficino tampoco escapa a la fuerza de la imagen de la caza. En el De vita, cuando aconseja cuidar la salud, recuerda con más fuerza la utilidad de conservar y potenciar nuestro intelecto:

Solo los sacerdotes de las musas, solo los cazadores del más alto bien y de la más alta verdad, son tan negligentes y desventurados, oh infamia, como para descuidar el instrumento con el cual son capaces de medir y captar el mundo todo" ${ }^{40}$.

No obstante, en Ficino se observa un mero uso ocasional. En Nicolás de Cusa la imagen se tematiza en un libro que es evidente que Bruno conoció. Con todo, de estos tres autores creemos que quien más fuerza ejerció en el Nolano fue Lulio ${ }^{41}$. Los aires de similitud

37 Para ver con más detalles la circulación del mito véase Ordine, El umbral en la sombra, pp. 137-146. También Yates, Giordano Bruno, pp. 332-335.

38 "Duobus modis in libro isto infinitatem considerari oportet; scilicet infinitatem, quae est secundum quid, subalternata. De istis infinitatibus erit liber iste. Quas venabimur per duodecim principia". Cfr. Lulio, R. (1959), Raimundi Lulli opera latina, 213-139: opera Messaniense, p. 281, Palmae Maioricarum. Este uso puede apreciarse en el resto de la obra luliana.

39 Cruz Hernández, M. (1977), El pensamiento de Ramon Llull, Valencia, Fundación Juan March/Editorial Castalia, pp. 318-323.

40 "Soli vero Musarum sacerdotes, soli summi boni veritatisque venatores tam negligentes pro nefas, tamque infortunati sunt, ut instrumentum illud, quo mundum universum metiri quoammodo et capere possunt, negligere penitus videantur". Ficino, M. (1989), Three books on life, New York, The Renaissance society of America, p. 111.

41 Está pendiente de hacerse una investigación rigurosa acerca de los lazos que se dan entre estos dos pensadores. Yates en su monumental obra (Giordano Bruno y la tradición hermética) ya advirtió que en ella estaba ausente un elemento de considerable importancia como era el lulismo. Cfr. Yates., F. A. (1983), Giordano Bruno y la tradición hermética, p. 10, Barcelona, Ariel. Con regusto luliano, Bruno publicó varias obras inspiradas en la peculiar lógica del pensador mallorquí. Tales obras fueron Clavis Magna (1579), De compendiosa architectura 
entre De gli eroici furori y una obra de Lulio, El libro del amigo y del amado, son varios: ambos mantienen una distinción entre la dignidad de una poética dedicada a las bellezas de lo divino frente a las bellezas mundanales, separan también los amores vulgares de los sagrados, toman como punto de orientación el Cantar de los cantares, así como comparten la misma estructura en el amor ${ }^{42}$ y muchas imágenes poéticas.

Hay un pasaje de Lulio en el que se apela a la caza con particular fuerza, y que bien pudiera pasar, con algún pequeño cambio, como parte de la obra de Bruno. En dicho pasaje se azuza a los perros que rastrean las huellas de la verdad:

126- ¡Ah, entendimiento y voluntad! Ladrad, y despertad a los grandes perros que duermen olvidando. ¡Ah, ojos! Llorad. ¡Ah, corazón! Suspira. ¡Ah, memoria! Acuérdate de la afrenta que hacen a mi Amado aquellos que Él ha honrado tanto ${ }^{43}$.

Los perros que duermen no son otra cosa que los pensamientos encaminados por las dos alas platónicas, entendimiento y voluntad. De los perros expresa el Nolano:

Entonces los canes, pensamientos de cosas divinas, devoran a este Acteón, haciendo que muera para el vulgo, para la multitud, liberado de las trabas de los sentidos perturbados, libre de la carnal prisión de la materia $(. . .)^{44}$.

Siguiendo el rastro de los canes que habrán de convertir al cazador en cazado encontramos una rica fuente de resonancias que cobran fuerza en todos los neoplatónicos. Esto no era así en el mismo Platón, que dice sin dudar en Eutidemo (290 c) que la caza no es labor propia del verdadero buscador del conocimiento:

-Ninguna de las artes relativa a la caza -respondió- va más allá de cazar o capturar, y una vez que la gente ha capturado lo que era objeto de su caza, no sabe qué uso hacer de él. Tanto es así que los cazadores y pescadores entregan sus presas a los cocineros y, a su vez, los geómetras, astrónomos y maestros de cálculo -pues también ellos son cazadores, ya que, en efecto, no producen sus figuras, sino que se limitan a encontrar las que existen-, como tampoco saben qué uso hacer de ellas, sino sólo cazarlas, entregan lo que han hallado a los dialécticos, para que lo utilicen. Por lo menos, así proceden quienes, de entre estos últimos, no han perdido por completo la cabeza ${ }^{45}$.

et complemento artis Lulli y De lulliano specierum scrutinio (1588). Aunque tradicionalmente se ha restringido su influencia a la lógica combinatoria, nosotros proponemos que hay elementos que emparentan De gli eroici furori con Lulio.

42 El amor en ambas se considera como movimiento doble del alma: cuanto más se sufre por la ausencia de lo divino más se ama y feliz se es, porque es más presente. Se juega con el par de contrarios ausencia es presencia y suplicio es placer.

43 Lulio, R. (1950), El libro del amigo y el amado, Barcelona, Juan Flors Editor, p. 76.

44 Furores, p. 183.

45 Platón (1982), Diálogos II, Madrid, Gredos. 
Los cazadores para Platón se sitúan un peldaño por debajo del filósofo, que posee visión arquitectónica del conocimiento. Los otros (menciona sobre todo a matemáticos) se dedican a aplicar de modo localizado su saber, pero sin escapar y sin ascender más allá de la provincia que dominan. La verdad es imperio grande, y más que gobernantes de provincias, se requiere del dominio de un verdadero monarca (el filósofo), que vea todo en perspectiva y sepa qué lugar ocupa cada cosa en el esquema general del saber. A la luz de estas consideraciones vemos que el solapamiento entre la figura del filósofo y el cazador es producto del neoplatonismo, más que del platonismo original. De aquellos bebe, entonces, Bruno.

Las distinciones, orientaciones y contextos de estos autores son diversos pero a la luz de estos pasajes, creemos que podemos enraizar el problema de la caza en Bruno no como algo colateral a la elección de un mito (el de Acteón). Más bien al contrario: la caza, como asunto latente en autores anteriores, orienta a Bruno a la hora de escoger el mito que deseara. La elección más conveniente, habida cuenta del éxito que tuvo el mito de Acteón en la poesía y la pintura del Renacimiento, era aprovecharlo inoculando diversos elementos, propios a Bruno y a algunos pensadores neoplatónicos que él debió leer. Entre esos elementos se hallaba, sin duda, la figuración de la caza, que halla fácil acomodo en el mito.

\section{Conclusiones}

Nuestra finalidad ha sido comprender el sentido profundo de Los heoricos furores de Giordano Bruno. Para esto, hemos expuesto la postura de Miguel Ángel Granada, que sugiere una lectura averroísta de esta obra del Nolano.

Es importante señalar que no podemos considerar esta obra bruniana como una obra averroísta, puesto que el furioso bruniano presenta una serie de caracteres que le otorgan peculiaridades tales que hacen que su sabio no sea el averroísta. Sus especifidades le hacen extraño a esa tradición. En efecto, se distingue de aquel en un hecho muy sencillo: el furioso no es aquel que, dedicado a la contemplación, tiene una vida feliz; antes bien, el furioso sufre y tiene ansiedades por ser consciente de lo inalcanzable de su pretensión. Más allá de esa razón presentamos otros indicios, y propusimos tres aspectos en los que Bruno es deudor de la tradición neoplatónica, que sin duda moldean la figura de sabio que propone: la incognoscibilidad de lo Uno, la importancia de lo visual y la caza de lo divino. Desligamos, pues, De gli eorici furori de un ámbito averroísta y lo entroncamos en la tradición neoplatónica.

Así, el furioso no alcanza en los términos averroístas (puramente racionales) el punto más alto de la verdad. El furioso emplea el "candelero" de la razón para desvanecer la multiplicidad de las sombras de este mundo hasta llegar a las especies inteligibles. Este candelero, apoyado en el bastón de la voluntad, puede tener un conocimiento sobre los apareceres que nos rodean, pero su luz no es suficiente para dejar vislumbrar el principio de lo real, aquello que Platón llamara Bien o Plotino Uno. 


\section{Bibliografía}

Bruno, Giordano (1985), De gli eroici furori, en Dialogui italiani, Firenze, Sansoni.

Bruno, Giordano (1987), Los heroicos furores, Barcelona, Tecnos..

Ayala Martínez, Jorge. M. (ed.) (1999), Averroes y los averroísmos. Actas del III congreso nacional de filosofía medieval, Zaragoza, Sociedad de Filosofía Medieval.

Cruz Hernández, M. (1977), El pensamiento de Ramon Llull, Valencia, Fundación Juan March/Editorial Castalia.

Dionisio, Pseudo (2007), Obras completas, Madrid, Biblioteca de autores cristianos.

Ficino, M. (1989), Three books on life, New York, The Renaissance society of America.

Garin, E. (1984), La revolución cultural del renacimiento, Madrid, Crítica.

Gilson, E. (2009), El ser y los filósofos, Pamplona, Eunsa.

Gombrich, E. H. (1986), Imágenes simbólicas, Madrid, Alianza.

Granada, M. A. (2002), Giordano Bruno: universo infinito, unión con Dios, perfección del hombre, Barcelona, Herder.

Granada, M. A. (2005), La reivindicación de la filosofía en Bruno, Barcelona, Herder.

Kristeller, P. O. (1986), El pensamiento renacentista y las artes, Madrid, Tecnos.

Kristeller, Paul O. (1982), El pensamiento renacentista y sus fuentes, México, FCE.

Kristeller, Paul O. (1970), Ocho filósofos del Renacimiento italiano, México, FCE.

Ordine, Nuccio (2008), El umbral de la sombra, Madrid, Siruela.

Platón (1982), Diálogos II, Madrid, Gredos.

Platón (1982), Diálogos IV, Madrid, Gredos.

Plotino (1998), Enéadas, Gredos, Madrid.

Praz, Mario (2005), Imágenes del Barroco, Madrid, Siruela.

Lulio, R. (1950), El libro del amigo y el amado, Barcelona, Juan Flors Editor.

Lulio, R. (1959), Raimundi Lulli opera latina, 213-139: opera Messaniense, Palmae Maioricarum.

Yates, Frances (1983), Giordano Bruno y la tradición hermética, Barcelona, Ariel. 
